\title{
Research on Marine Ecological Civilization Policies in Shandong Province Based on Content Analysis
}

\author{
Jun Ma \\ ${ }^{1}$ School of Public Affairs, University of Science and Technology of China, Hefei, China \\ ${ }^{2}$ Xindu Primary School, Economic and Technological Development Zone, Weihai, China \\ Email: mary3180robert@163.com
}

How to cite this paper: Ma, J. (2020) Research on Marine Ecological Civilization Policies in Shandong Province Based on Content Analysis. Open Journal of Ecology, 10, 264-288.

https://doi.org/10.4236/oje.2020.105017

Received: April 10, 2020

Accepted: May 19, 2020

Published: May 22, 2020

Copyright () 2020 by author(s) and Scientific Research Publishing Inc. This work is licensed under the Creative Commons Attribution International License (CC BY 4.0).

http://creativecommons.org/licenses/by/4.0/

\section{(c) (i) Open Access}

\begin{abstract}
The policies of marine ecological civilization involve multiple policy areas such as marine economy, marine environment, and marine society. This paper sorted out 54 related policies of marine ecological civilization in Shandong Province, constructed a co-word matrix of policy keywords, and used co-word analysis method to conduct quantitative analysis. Through the measurement of policy network centrality, policy theme groups and structural holes, the coordination of policy contents and the centrality of policy points were analyzed. The study has found that among the comprehensive policies for marine ecological civilization construction in Shandong Province, the marine ecological environmental protection policies have more focuses and have formed a relatively complete system, but the relevancy of the policy points of marine science and technology innovation related to marine support policies is not high, and the support for marine environmental protection technology innovation is not strong. These discoveries are also reflected in the subsequent content analysis of marine social support policies, and they also affect the coupling degree between the marine ecological environment and marine ecological society in Shandong Province to a certain extent.
\end{abstract}

\section{Keywords}

Content Analysis, Marine Ecological Civilization, Policy Text, Content Coordination

\section{Introduction}

The policies of marine ecological civilization involve multiple policy areas such as marine economy, marine environment and marine society. They are the 
summation of a series of public policies adopted by a certain region to promote the construction of marine ecological civilization. This paper will study the construction of marine ecological civilization from a policy perspective, and propose more targeted and operable countermeasures in combination with the evaluation index system. This paper will focus on the analysis of the policy groups of Shandong Province's marine ecological documents that have been issued since 2001 when the Tenth Five-Year Implementary Plan for the Construction of "Marine Shandong Province" was issued. This paper will focus on the following issues: What policies have been mainly introduced by relevant departments of marine administration in Shandong province and how should these policies be classified; how are the contents of the policy groups of marine ecological civilization construction in Shandong province coordinated? Thereafter, this paper will sort out and classify related policies of marine ecological civilization in Shandong Province, construct a co-word matrix of policy keywords, and use co-word analysis to quantify them. Then, this paper will draw a social network relationship diagram of the core content of the policies, and analyze the coordination of the policy content and the centrality of the policy point through the measurement of the policy network centrality, policy subject groups, and structural holes, with a view to providing a reference for the subsequent policy introduction.

\section{Shandong Province's Marine Ecological Civilization Policies and Their Formulation}

\subsection{Review of the Marine Ecological Civilization Policies in Shandong Province}

With regard to the text selection of marine ecological civilization policies in Shandong Province, this thesis divides China's marine ecological civilization-related policies into three stages [1]:

The first stage was from 1982 to 1995 . During this period, China's marine ecological civilization policies were promulgated in a large number and with a high frequency. In legal area, there were three main laws, respectively Marine Environmental Protection Law of the People's Republic of China, Maritime Traffic Safety Law of the People's Republic of China, and Fisheries Law of the People's Republic of China; in regulations area, there were mainly 18 regulations include Regulations of the People's Republic of China on Foreign Cooperation in the Exploitation of Offshore Oil Resources, Regulations of the People's Republic of China on the Management of Environmental Protection of Offshore Oil Exploration and Development, Regulations of the People's Republic of China on the Management of the Prevention of Pollution of Marine Areas by Ships, Regulations of the People's Republic of China on the Implementation of Protection of Aquatic Wildlife, Regulations of the People's Republic of China on the Management of Marine Dumping, and Regulations on the Prevention and Treatment of Marine Environmental Pollution and Damage by Coastal Con- 
struction Projects, and there were three departmental regulations, respectively Measures for the Implementation of the Regulations of the People's Republic of China on Environmental Protection for Offshore Oil Exploration and Development, Measures for the Implementation of the Regulations of the People's Republic of China on the Management of Marine Dumping, and Measures for the Implementation of Regulations on the Administration of Laying Submarine Cable Pipelines.

The second stage was from 1996 to 2000, during which marine laws, regulations and rules at the national level were less promulgated. In legal area, there was only one law, i.e. Law of the People's Republic of China on the Exclusive Economic Zone and the Continental Shelf, in regulations area, there was only Regulations of the People's Republic of China on the Administration of Foreign-Related Marine Scientific Research. At the same time, with the large increase in marine development activities, the pressure on the marine environment gradually increased, and China strengthened the revision and modification of laws and regulations formulated in the previous stage.

The third stage is from 2001 to the present. The development and utilization of marine resources has played an increasingly greater role in promoting China's economic and social development. This has also made the formulation of domestic marine policies usher in a new peak. During this period, China has promulgated five laws, respectively Law of the People's Republic of China on the Use of Sea Areas, Port Law of the People's Republic of China, Law of the People's Republic of China on the Protection of Islands, Law of the People's Republic of China on the Navigation Channel, and Law of the People's Republic of China on the Exploration and Development of Deep-Sea Seabed Resources. Related laws such as Fisheries Law, Marine Environmental Protection Law, Customs Law, Port Law, and Maritime Traffic Safety Law have been revised, and Marine Environmental Protection Law of the People's Republic of China was amended three times in 2013, 2016 and 2017, which fully reflects the party and country's emphasis on marine environmental protection and the construction of marine ecological civilization; in the field of regulations, there are Regulations of the People's Republic of China on International Maritime Transport and Regulations on the Prevention and Control of Pollution Damage to the Marine Environment by Marine Engineering Construction Projects; and there are three relevant departmental regulations, respectively Measures for the Implementation of Marine Administrative Penalties, Provisions for the Protection of Submarine Cable Pipelines and Administrative Measures for the Issuance of Licenses for the Marine Dumping of Waste.

In order to systematically and accurately analyze the current formulation of marine ecological civilization policies in Shandong Province and the policy coordination, this paper mainly reviews Shandong Province's marine ecological civilization polices from 2001 to the present [2]. At this stage, Shandong Province has formulated Tenth Five-Year Implementary Plan for the Construction of 
"Marine Shandong Province" in 2001, has formulated Regulations of Shandong Province on the Administration of the Use of Sea Areas, Regulations of Shandong Province on Marine Environmental Protection, has promulgated Marine Function Zoning of Shandong Province and "Blue Sea Action" Plan of Shandong Province, and has actively promoted the three basic systems of marine function zoning, approval of sea area authority and paid use of sea areas. Shandong province has initially established a network of marine environmental monitoring and disaster prevention, enabling marine management to enter a legal, scientific and standardized track. In 2007, Shandong Provincial Party Committee and Provincial Government issued Decision on Vigorously Developing the Marine Economy and Building a Strong Marine Economy Province, which proposed that we should continue to develop the sea through science and technology and innovate institutions and mechanisms, and strive to promote coordinated development of the primary, secondary and tertiary marine industries, the coordinated development of the marine economy and the terrestrial economy, and the coordinated development of the exploitation and protection of marine resources. In 2011, the Development Plan of Shandong Peninsula Blue Economic Zone was approved by the State Council and was officially promoted as a national strategy, marking the development of Shandong's marine ecological civilization as an important part of the economic and social strategy and the national regional coordinated development strategy. In 2016, seven departments of Shandong Province, including the Marine and Fishery Department, the Development and Reform Commission, and the Department of Finance, jointly promulgated Plan for the Construction of Marine Ecological Civilization in Shandong Province, marking that the construction of Shandong Marine Ecological Civilization has entered a stage of comprehensive construction.

In the selection of marine ecological civilization policy literature, this paper follows the following steps:

1) Using the policy database of Pkulaw to search the marine ecological civilization policies from 2001 to March 2019. In order to ensure the efficiency and accuracy of policy literature retrieval, this paper adopted the data source of "local regulations and rules" in the retrieval option of "effectiveness level and issuing department" according to the definition of the research scope mentioned above, and the administrative departments of marine ecological civilization construction in Shandong province retrieved include the Provincial Party Committee, Provincial Government, Provincial People's Congress, the Department of Marine Affairs and Fishery, the Development and Reform Commission, the Department of Finance, the Department of Forestry, the Department of Environmental Protection and other relevant administrative agencies, and their published policies were retrieved and extracted.

2) Determining the search keywords. In this paper, keywords were determined based on the Thesaurus of Official Documents of the State Council revised by the General Office of the State Council in 1997, and keywords such as "ocean", 
"ecology", "waters", "islands", and "fisheries" were selected. The policy texts were selected with keywords such as "regulations", "outlines", "specifications", "opinions", "suggestions", "measures", "provisions", “decisions", "notifications", "schemes", etc. Then, keywords were entered in the search bar for retrieval and extraction.

3) Checking and filling the gaps in the relevant policy systems. This was done by searching the official website of the Provincial Party Committee, Provincial Government, Provincial People's Congress, and other administrative departments of marine ecological civilization construction such as the Department of Oceans and Fisheries (now the Department of Natural Resources), the Department of Agriculture (now the Department of Rural Agriculture), the Department of Environmental Protection (now the Department of Ecological Protection) and other competent authorities, so as to further check and fill in vacancies in policies that have not been collected by the Pkulaw Database.

Finally, the relevant policy texts of marine ecological civilization construction in Shandong Province were processed, and duplicate documents, irrelevant documents and invalid documents were eliminated, and a total of 54 policy texts related to marine ecological civilization were retrieved.

As shown in Figure 1, after the Development Plan of Shandong Peninsula Blue Economic Zone submitted to the State Council in 2011 was approved and the construction of Shandong Peninsula Blue Economic Zone was officially rose to a national development strategy, great importance has been attached to the development of marine ecological civilization, and the number of policies formulated and issued has been greatly increased. In particular, 2015-2017 is an important stage for the formulation and renewal of marine ecological civilization policies in Shandong province. The scope has also developed from the single marine economic policies from 2011 to 2013 to a policy system of marine ecological civilization based on comprehensive planning policies and with coordinated development of marine economic, marine environmental and marine

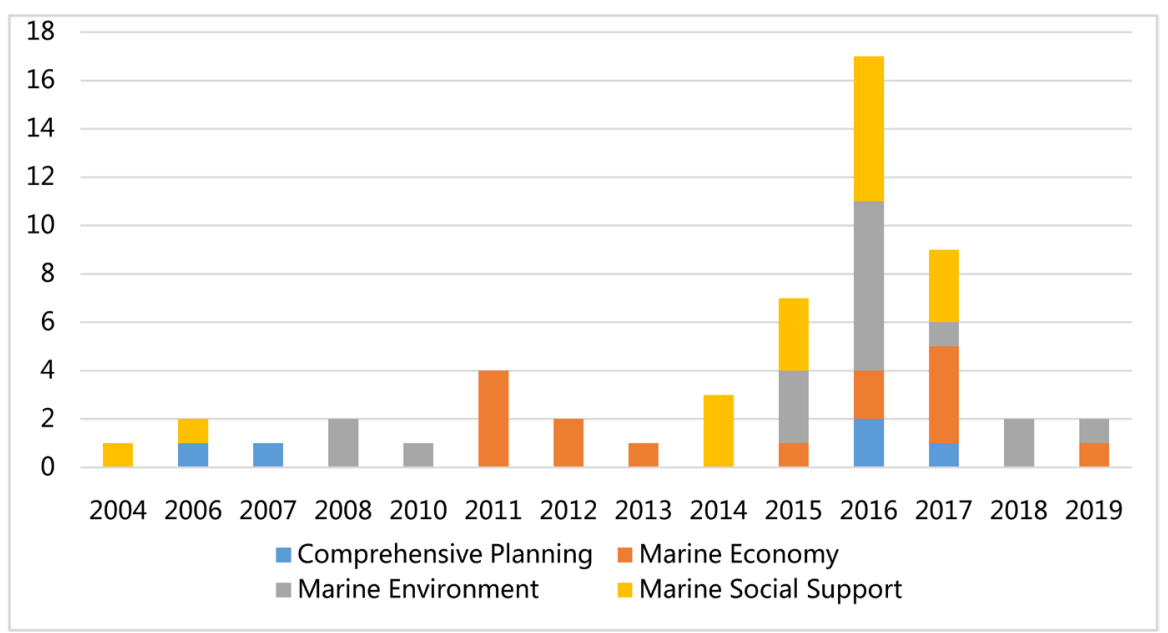

Figure 1. Policy Formulation of Marine Ecological Civilization in Shandong Province from 2006 to 2019 (The data are from Shandong provincial bureau of statistics). 
social support policies.

\subsection{Classification of Marine Ecological Civilization Policies in Shandong Province}

The marine ecological civilization policies can be categorized into meta-policies, basic policies and specific polices at the policy level [3]. Among them, the marine ecological civilization meta-policies refer to a general term for a set of ideas and methods used to guide and regulate the government's marine ecological civilization policy behaviors, that is, "policies for formulating marine ecological civilization policies". The basic policies of marine ecological civilization are the comprehensive policies of marine ecological civilization at the national and local levels. They are programs of action formulated by a country in order to achieve its goal and vision in the construction and management of marine ecological civilization. Specific marine policies refer to the specific code of action or code of conduct formulated by relevant departments in order to further implement the basic marine policies, such as marine shipping policies, marine resources development policies, marine ecological protection policies, etc. Compared with the basic marine policies, the specific marine policies have obvious pertinence, that is, they refer to specific industries and are subdivisions under the framework of the basic marine policies.

From the purpose level of marine ecological civilization policies, Wang Gang (2012) believes that marine ecological civilization policies can be categorized into marine development policies and marine ecological protection policies [4]. Marine development policies are the marine policy on marine utilization formulated by the government for economic considerations, mainly including three aspects of marine fishery development, marine resources development and marine transportation development. Marine protection policies include marine environmental protection policies and marine rights and interests protection policies, such as Technical Regulations on the Total Amount of Pollutants Entering the Sea and the Monitoring of Environmental Quality in the Estuary Area and Technical Regulations on the Monitoring of Marine Nature Reserves.

From the scope level of marine ecological civilization policies, marine policies can be divided into industrial marine policies and comprehensive marine policies. The industrial marine policies belong to the specific marine policies. They are means to achieve the objectives of the basic marine policies and to implement the specific implementation rules of the basic policies. Comprehensive marine policies, on the other hand, refer to the "comprehensive overall policies covering the development, utilization, protection, maintenance and management of national maritime rights and interests, resources and the environment at the highest level". They are mainly reflected in the overall coordination of marine policies on marine resources, marine environment, marine rights and interests and public welfare services.

This paper constructs an evaluation index system from the aspects of marine 
economy, marine environment and marine social support in Shandong province, and evaluates the marine ecological civilization construction in Shandong Province. Therefore, this paper will also build an analytical framework for the policy system of marine ecological civilization construction in Shandong province from these three purposes. First, a comprehensive plan for the construction of marine ecological civilization in the province needs to be formulated to promote the coordinated development of marine economy, marine environment, and marine society support in Shandong Province. Second, the advantages of Shandong's marine fishery resources and mineral resources need to be brought into play, and they should be transformed into economic and commercial values. Third, in the development and utilization of marine resources, the protection of the marine ecological environment should be paid attention to so as to realize the green sustainable development of marine ecological civilization construction in Shandong Province. Fourth, the management of sea areas, fishery personnel and fishing vessels should be strengthened, and the research and development investment in marine education and technology should be increased, so as to promote scientific and technological innovation, promote the transformation and upgrading of marine traditional industries, accelerate the development of marine service industry, and thereby improve the quality of development in the construction of marine ecological civilization. Policy Framework System of Marine Ecological Civilization in Shandong Province is show in Figure 2.

According to the approaches, thoughts and data sources provided above, this paper makes classified statistics on the 54 marine ecological civilization construction policies in Shandong province from 2001 to 2019 based on their main target categories, and excludes some policies that do not conform to the four major types. The statistical results are shown in Table 1.

From the statistical data in Table 1, it can be found that among all the policies for marine ecological civilization, the numbers of policies for marine economy, marine environment and marine social support are relatively balanced, except that the policies for comprehensive planning are few.

In terms of time and content, the comprehensive planning policies are mainly concentrated in 2006-2007 and 2016-2017, which is similar to the time of the

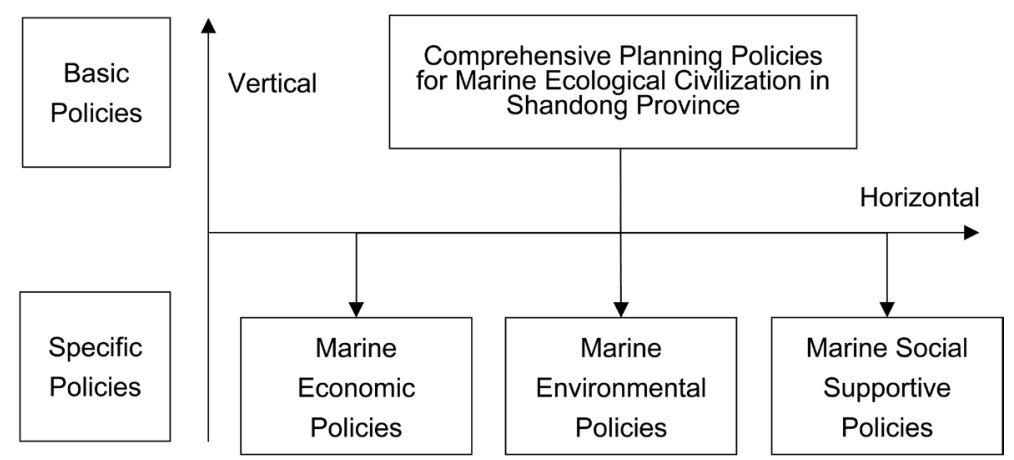

Figure 2. Policy framework system of marine ecological civilization in Shandong province. 
Table 1. Classified statistics of marine ecological civilization construction policies in Shandong province.

\begin{tabular}{|c|c|c|}
\hline Target Type & Explanation & Quantity \\
\hline $\begin{array}{l}\text { Comprehensive } \\
\text { Planning }\end{array}$ & $\begin{array}{l}\text { The overall plans for the future goals of marine ecological } \\
\text { civilization based on the development of the region, industry, } \\
\text { environment, science and technology }\end{array}$ & 5 \\
\hline Marine Economy & $\begin{array}{l}\text { Promoting the development of the marine economy by giving full } \\
\text { play to the advantages in fishery, mineral resources and marine } \\
\text { transportation }\end{array}$ & 15 \\
\hline $\begin{array}{c}\text { Marine } \\
\text { Environment }\end{array}$ & $\begin{array}{l}\text { The protection of marine ecological environment, mainly including } \\
\text { pollution and disaster prevention, seawater quality inspection and } \\
\text { marine ecological compensation }\end{array}$ & 17 \\
\hline $\begin{array}{c}\text { Marine Social } \\
\text { Support }\end{array}$ & $\begin{array}{l}\text { Strengthening the management of sea areas, fishery personnel and } \\
\text { fishing vessels, improving the marine education and scientific and } \\
\text { technological innovation system, promoting the transformation and } \\
\text { upgrading of traditional marine industries, and supporting the } \\
\text { cultivation of new marine economies }\end{array}$ & 17 \\
\hline
\end{tabular}

five-year planning policies. The policies of marine economy are mainly concentrated in 2012-2013 and 2017-2018, which are mainly focused on modern fishery parks related to aquaculture and oceans. The policies on marine environment are mainly concentrated in 2015-2016 and 2018-2019, mainly covering marine protection areas, marine disaster prevention and control, and marine ecological and environmental protection. The policies of marine social support are mainly concentrated in 2014-2015 and 2016-2017, which mainly involve management of fishery and fishing boats, marine scientific and technological innovation, and management of waters and islands respectively.

\subsection{Analysis on the Main Body of Policy Formulation of Marine Ecological Civilization in Shandong Province}

In terms of the main body of policy formulation of marine ecological civilization, among the various types of marine ecological civilization policies promulgated by Shandong province since 2006, there are two local regulations promulgated by provincial people's congress and its standing committee, namely Regulations on the Use and Management of Sea Areas of Shandong Province and Regulations on Marine Environmental Protection of Shandong Province. There are seven local administrative regulations promulgated by the provincial government, and 45 administrative rules and regulations of provincial departments.

Among the 54 policies of various types, the main body which participated in the formulation of the policies involves 8 power organs and administrative departments, including Shandong Provincial People's Congress and its standing committee, Provincial Government, the Department of Marine Affairs and Fishery (now the Oceanic Administration), the Development and Reform Commission, the Department of Ecology and Environment, the Department of Finance, etc. The main body of participation presents the characteristics of diversification. However, the coordination of consultation and decision making 
among policy makers is insufficient on the whole, and the number of joint decisions only accounts for about a quarter of the total number of policies. It can be seen that the synergy of policy release is not high, and the policy making process can be summarized as a simple multivariate decision making model.

As shown in Figure 3, as many as 39 marine ecological civilization policies in Shandong province were issued by a single agency or department, accounting for nearly three-quarters of all the policies. Eight policies were jointly issued by two agencies or departments; 7 jointly issued by three or more agencies or departments. The departments or agencies that issued the documents separately were provincial Department of Marine Affairs and Fishery (now the Oceanic Administration) and Provincial Government. The Department of Marine Affairs and Fishery (now the Oceanic Administration) with the Department of Finance, and the Department of Marine Affairs and Fishery (now the Oceanic Administration) with the Development and Reform Commission are the major co-issuing departments.

Among the 54 policy samples, the Department of Marine Affairs and Fisheries (now the Oceanic Administration) issued the most policies separately, with a total of 30 policies on marine ecological civilization, mainly including marine economic planning, marine ranching, marine disaster prevention, marine ecological protection, fishery and vessel management. Subsequently, Shandong Provincial Government separately issued seven marine ecological civilization policies, mainly including marine ecological protection, development of blue economic zone and construction of a strong marine province. Shandong Provincial People's Congress and its standing committee separately issued two policies concerning the use and management of sea areas and marine environmental protection.

From the situation of joint promulgation of departments, relatively close cooperative relationships have been established between Shandong Provincial

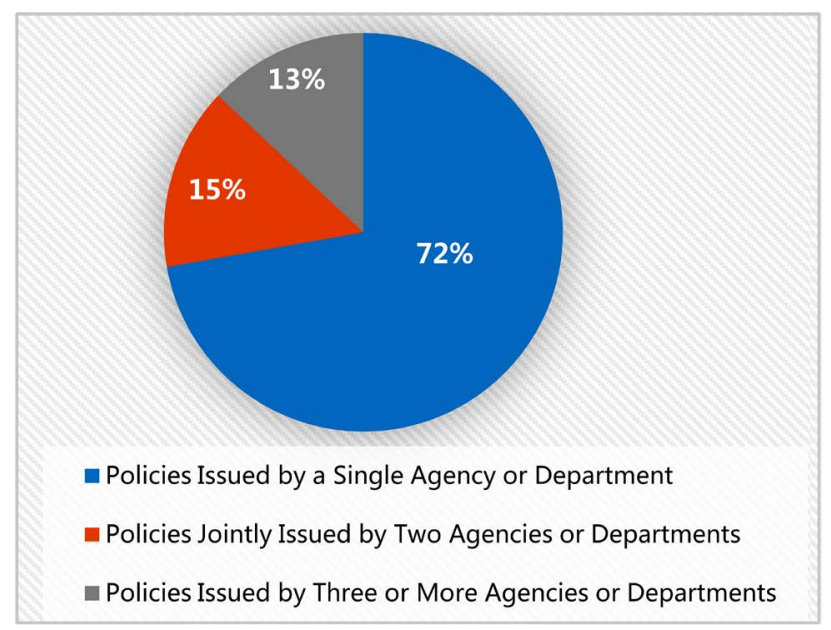

Figure 3. Publication of Policy-Making Bodies of Marine Ecological Civilization in Shandong Province from 2006 to 2019 (The data are from Shandong provincial bureau of statistics). 
Department of Marine Affairs and Fishery (now Oceanic Administration) and the Department of Finance, and the Department of Marine Affairs and Fishery (now Oceanic Administration) and the Development and Reform Commission. Among them, Shandong Provincial Department of Marine Affairs and Fishery (now Oceanic Administration) and the Department of Finance jointly issued six marine ecological civilization policies, which mainly involve the administration of the right to use the sea areas of islands, marine ecological compensation, and the construction of modern fishery parks. The Department of Marine Affairs and Fishery (now Oceanic Administration) and the Development and Reform Commission jointly issued two policies on marine ecological civilization, mainly involving the construction of marine ranching and marine granaries. In terms of joint promulgation by three agencies or departments, Shandong Provincial Department of Marine Affairs and Fishery (now Oceanic Administration) has carried out close cooperation with the Department of Finance and the Development and Reform Commission on the construction, implementation and management of modern fishery parks. In terms of joint promulgation by multiple agencies or departments, with the Department of Marine Affairs and Fishery (now Oceanic Administration) as the core, Shandong province has formed a cooperative network involving the Development and Reform Commission, the Department of Finance, the Department of Environmental Protection, the Commission of Economy and Information Technology, the Department of Agriculture and other departments to formulate policies on marine ecological civilization, and the policies made mainly involve the construction and implementation of marine ecological civilization, the innovative development of marine economy and so on.

The main body composition of the public decision-making system determines the process and mode of policy making and directly affects the result of policy selection. Meanwhile, due to the difference in policy value orientation and the focus and attention of different policy makers, the value concepts of the policy results are also different. Known from the analysis of the above, the marine ecological civilization policies in Shandong province presents the following characteristics: First, the policy-making participants are diversified. In addition to the Department of Marine Affairs and Fishery (now Oceanic Administration), which is a major department directly related to the construction of marine ecological civilization, the Department of Finance, the Development and Reform Commission and other administrative departments also participate in the policy-making activities to a certain extent. Second, under the decision-making mode of multi-subject participation in policy making, Shandong Provincial Department of Marine Affairs and Fishery (now Oceanic Administration) pays the most attention to the policy issues related to the construction of marine ecological civilization, and the number of policy texts formulated by it accounts for the largest proportion, while the Department of Ecology and Environment, in terms of marine environmental protection, is only responsible for the environmental function zoning of offshore waters and issues concerning the land-based pollu- 
tion emissions; Third, in all of the policy samples, the policy texts jointly issued by multiple agencies or departments account for a small number, meaning that the policy making is dominated by the single decision-making mode, and the joint decision-making is very rare. However, with the introduction of new governance concepts and the development of interdisciplinary research, the multiple collaborative decision-making mode of marine ecological civilization construction is gradually formed.

\section{Coordination Analysis of Policy Text Contents}

Policy documents are the reflection of government behaviors and the most effective objective basis to grasp the core value of policies, reflecting the working direction and priorities of policy makers in a certain period of time. This paper adopts content analysis method, converts the linguistic representation of particular textual materials into quantitative representation, quantifies the policy contents through the analysis of literature contents, uses Excel software to conduct statistics of basic data, constructs a common word matrix of marine ecological civilization policies, and generates a visual social network diagram of policy core contents with the help of social network analysis tool Ucinet, so as to present the status quo and policy priorities of Shandong province's marine ecological civilization policy construction network in a visual way, and explore the real intention behind the policy documents and the future development trend.

\subsection{Choice of Policy Texts}

The policy data should fully reflect the structural system of marine ecological civilization policies, and facilitate the comparison of policy focuses [5]. This paper takes the Shandong Province's marine ecological civilization policies from 2006 to March 2019 as the research object. The selected policy texts were collected from the data published on the websites of Pkulaw, the Provincial Government, the Provincial People's Congress, the Department of Marine Affairs and Fishery (now Oceanic Administration), the Department of Environmental Protection (now the Department of Ecology and Environment), the Development and Reform Commission, the Department of Finance and other relevant administrative agencies. In order to ensure the relative completeness and pertinence of the data, this study sorted and selected the policy texts in accordance with the following principles: First, the issuing unit must be the Shandong Provincial Government and its direct agencies; Second, the policies should be directly related to the construction of marine ecological civilization; Third, the type of policies should be determined, and this paper mainly selects documents that reflect government policies, such as laws, regulations, plans, opinions, measures, detailed rules, ordinances, and notifications, and does not include documents such as industry standards. Finally, 54 policy texts of marine ecological civilization were sorted out and taken as the research object, including 5 comprehensive planning policies, 15 marine economic policies, 16 marine environment policies, and 17 
marine social support policies.

This study takes these 54 policies that are closely related to the construction of marine ecological civilization as the necessary analysis unit for the content analysis method. After selecting the policy texts, the reliability test of the coding consistency and classification accuracy of the main judge is also carried out by comparing the degree of mutual agreement among several text judgment analysts [6]. In order to ensure the objectiveness and preciseness of the text analysis results and reduce the interference of subjective factors, the coding of 54 marine ecological civilization policy texts in this paper was completed with three doctoral students studying public policy. It is generally believed that if the consistency ratio between different judges reaches $80 \%$, the coding result of the main judge is acceptable. Through the reliability test of the two evaluation results, and after calculation and adjustment, the consistency ratio of the three judges reached $92.2 \%$, which obviously ensures the acceptability of the encoding result of the main judge of the texts.

\subsection{Keyword Frequency Analysis of Policy Samples}

An analysis unit refers to a unit defined as a minimum analysis metric [6]. In this study, the text of a marine ecological civilization policy in Shandong Province are used as an analysis unit, and words related to the construction of ecological civilization are extracted or generalized, and the policy points distributed in them are selected so as to extract the information in the policy samples and carry out quantitative processing. In order to accurately and comprehensively reflect the policy points of each marine ecological civilization policy, this paper first extracts the keywords of the policy contents. In particular, the category of one particular policy and the number of keywords in each analysis unit are not taken into account at the beginning of keyword extraction [7]. In order to ensure the validity of the summary and statistics of policy points, on the basis of reflecting the content and purpose of the policies scientifically and objectively, synonyms like "marine ecological protection" and "marine ecological restoration", "marine disaster management" and "marine disaster prevention", and hyponyms and superordinates like "marine regulations system" and "sea-related policy system" were merged. Secondly, the keywords of marine ecological civilization policies in Shandong Province and their frequency of occurrence were separately counted by EXCEL, and the keywords were sorted in descending order according to the frequency of occurrence, so as to avoid the interference of low frequency words to quantitative analysis.

After the above data standardization and cleaning, the keywords of Shandong provincial marine comprehensive policies, marine economic policies, marine environmental policies and marine social support policies were selected separately. In comprehensive policies of marine ecological civilization in Shandong province, 44 high-frequency words were obtained, with a cumulative frequency of 160. The statistical results are shown in Table 2. 
Table 2. High-Frequency Keywords for Comprehensive Policy Samples of Marine Ecological Civilization in Shandong Province.

\begin{tabular}{|c|c|c|c|c|c|c|c|}
\hline Keywords & Frequency & Keywords & Frequency & Keywords & Frequency & Keywords & Frequency \\
\hline $\begin{array}{l}\text { Marine Technological } \\
\text { Innovation }\end{array}$ & 5 & $\begin{array}{l}\text { Marine Function } \\
\text { Zoning }\end{array}$ & 4 & $\begin{array}{c}\text { Marine Strategic } \\
\text { Emerging Industries }\end{array}$ & 3 & Yellow River Delta & 3 \\
\hline $\begin{array}{c}\text { Marine Ecological } \\
\text { Protection and } \\
\text { Restoration }\end{array}$ & 5 & $\begin{array}{c}\text { Transformation of } \\
\text { Marine Scientific and } \\
\text { Technological } \\
\text { Achievements }\end{array}$ & 4 & $\begin{array}{c}\text { Intensive Utilization of } \\
\text { Natural Resources }\end{array}$ & 3 & $\begin{array}{l}\text { Orderly Development of } \\
\text { Coasts }\end{array}$ & 3 \\
\hline $\begin{array}{c}\text { Marine } \\
\text { Environmental } \\
\text { Monitoring }\end{array}$ & 5 & $\begin{array}{l}\text { Marine Law } \\
\text { Enforcement }\end{array}$ & 4 & $\begin{array}{l}\text { Marine High-Tech } \\
\text { Industries }\end{array}$ & 3 & $\begin{array}{l}\text { Optimize the Industrial } \\
\text { Structure }\end{array}$ & 3 \\
\hline $\begin{array}{c}\text { Land-Sea } \\
\text { Coordination }\end{array}$ & 5 & Marine Economy & 4 & $\begin{array}{l}\text { Marine Ecological } \\
\text { Redline }\end{array}$ & 3 & Marine Industries & 3 \\
\hline Marine Tourism & 5 & $\begin{array}{c}\text { Powerful Marine } \\
\text { Province }\end{array}$ & 4 & Modern Fishery & 3 & $\begin{array}{l}\text { Marine Petrochemical } \\
\text { Industry }\end{array}$ & 3 \\
\hline $\begin{array}{l}\text { Integrated Marine } \\
\text { Management }\end{array}$ & 5 & $\begin{array}{l}\text { Governing the Ocean } \\
\text { According to Laws }\end{array}$ & 4 & Blue Economic Zone & 3 & $\begin{array}{l}\text { Comprehensive Utilization of } \\
\text { Seawater }\end{array}$ & 3 \\
\hline $\begin{array}{l}\text { Marine Disaster } \\
\text { Prevention }\end{array}$ & 5 & “Three Bays” Area & 4 & Pilot Demonstrations & 3 & Marine Ecosystem & 3 \\
\hline $\begin{array}{c}\text { Marine } \\
\text { Environmental } \\
\text { Protection }\end{array}$ & 5 & $\begin{array}{l}\text { Marine Ecological } \\
\text { Compensation }\end{array}$ & 4 & $\begin{array}{c}\text { Sustainable } \\
\text { Development }\end{array}$ & 3 & $\begin{array}{c}\text { Industrial Upgrading and } \\
\text { Transformation }\end{array}$ & 3 \\
\hline $\begin{array}{l}\text { Ocean Development } \\
\text { and Protection }\end{array}$ & 4 & $\begin{array}{c}\text { Prevention and } \\
\text { Control of Marine } \\
\text { Pollution }\end{array}$ & 4 & $\begin{array}{l}\text { Marine Technology } \\
\text { Innovation Platform }\end{array}$ & 3 & $\begin{array}{l}\text { Marine Ecological Civilization } \\
\text { System Entrepreneurship }\end{array}$ & 3 \\
\hline $\begin{array}{l}\text { Marine Carrying } \\
\text { Capacity }\end{array}$ & 4 & $\begin{array}{c}\text { Marine Conservation } \\
\text { Areas }\end{array}$ & 3 & $\begin{array}{l}\text { Offshore Ecological } \\
\text { Environment }\end{array}$ & 3 & $\begin{array}{c}\text { Marine Ecology } \\
\text { Demonstration Construction }\end{array}$ & 3 \\
\hline
\end{tabular}

In marine economic policies, 42 high-frequency words were obtained, with a cumulative frequency of 180 . The statistical results are shown in Table 3.

In marine environmental policies, 41 high-frequency words were obtained, with a cumulative frequency of 144 . The statistical results are shown in Table 4.

In marine social support policies, 40 high-frequency words were obtained, with a cumulative frequency of 108 . The statistical results are shown in Table 5.

\subsection{Node Centrality Analysis of Policy Social Networks}

1) Drawing Network Diagram

According to the high-frequency words of the ecological civilization policies of Shandong Province, $44 * 44$ co-word matrixes of policy keywords for marine ecological civilization construction policies were constructed. In the matrixes, the number of diagonal lines is the total number of times a keyword appears, and the data in row A and column B is the number of times that keyword A and keyword B appear simultaneously in the innovation policy set. After loading the generated matrixes into the Netdraw visualization software, the social network diagrams of keywords for marine ecological civilization policies in Shandong 
Table 3. High-frequency keywords for marine economic policy samples of marine ecological civilization in Shandong province.

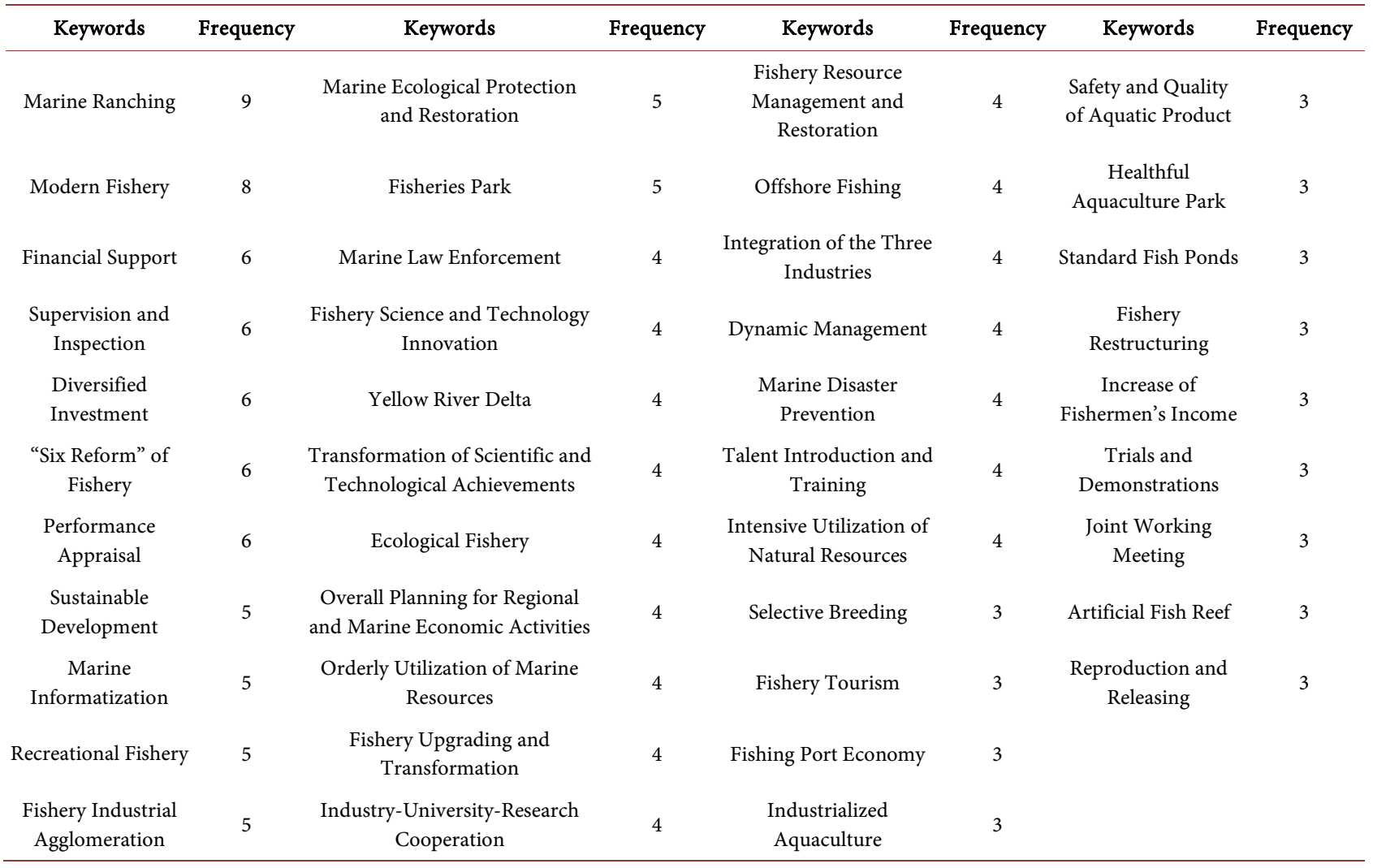

Table 4. High-frequency keywords for marine environmental policy samples of marine ecological civilization in Shandong province.

\begin{tabular}{|c|c|c|c|c|c|c|c|}
\hline Keywords & Frequency & Keywords & Frequency & Keywords & Frequency & Keywords & Frequency \\
\hline $\begin{array}{l}\text { Marine Ecological } \\
\text { Protection and Restoration }\end{array}$ & 9 & $\begin{array}{l}\text { Marine Environmental } \\
\text { Protection }\end{array}$ & 5 & Marine Forecasting & 3 & Offshore Environment & 2 \\
\hline $\begin{array}{l}\text { Marine Disaster } \\
\text { Prevention }\end{array}$ & 8 & $\begin{array}{l}\text { Marine Environmental } \\
\text { Monitoring }\end{array}$ & 4 & $\begin{array}{l}\text { Marine Pollution } \\
\text { Accident }\end{array}$ & 3 & $\begin{array}{c}\text { Marine Information } \\
\text { Release }\end{array}$ & 2 \\
\hline $\begin{array}{l}\text { Prevention and Control of } \\
\text { Marine Pollution }\end{array}$ & 7 & Marine Function Zoning & 4 & $\begin{array}{c}\text { Marine Resources } \\
\text { Conservation }\end{array}$ & 3 & $\begin{array}{l}\text { Diversified Investment } \\
\text { and Financing }\end{array}$ & 2 \\
\hline Land-Sea Coordination & 7 & $\begin{array}{l}\text { Marine Ecological } \\
\text { Civilization Construction }\end{array}$ & 4 & $\begin{array}{l}\text { "Gulf Manager" } \\
\text { System }\end{array}$ & 2 & $\begin{array}{c}\text { Marine Conservation } \\
\text { Areas }\end{array}$ & 2 \\
\hline Supervision and Inspection & 5 & Sustainable Development & 3 & $\begin{array}{l}\text { Landscape and } \\
\text { Cultural Relics }\end{array}$ & 2 & Graded Alert & 2 \\
\hline $\begin{array}{l}\text { Marine Ecological } \\
\text { Compensation }\end{array}$ & 5 & Protected Natural Area & 3 & $\begin{array}{c}\text { Public Opinion } \\
\text { Guidance }\end{array}$ & 2 & Marine Law Enforcement & 2 \\
\hline $\begin{array}{l}\text { Classified Regional } \\
\text { Management }\end{array}$ & 5 & Fund Supervision & 3 & Marine Economy & 2 & $\begin{array}{c}\text { Marine Engineering } \\
\text { Project }\end{array}$ & 2 \\
\hline Marine Ecological Redline & 5 & $\begin{array}{l}\text { Sewage Outlet } \\
\text { Management }\end{array}$ & 3 & $\begin{array}{c}\text { Total Sewage } \\
\text { Discharge Control }\end{array}$ & 2 & $\begin{array}{c}\text { Control of Pollution } \\
\text { Sources }\end{array}$ & 2 \\
\hline Special Protection Areas & 5 & $\begin{array}{c}\text { Rational Use of Marine } \\
\text { Resources }\end{array}$ & 3 & $\begin{array}{l}\text { Marine Technological } \\
\text { Innovation }\end{array}$ & 2 & & \\
\hline Marine Ecosystem & 5 & Biodiversity & 3 & $\begin{array}{l}\text { Coordinated } \\
\text { Development }\end{array}$ & 2 & & \\
\hline Financial Support & 5 & Coastline Restoration & 3 & $\begin{array}{c}\text { Marine Biological } \\
\text { Resources }\end{array}$ & 2 & & \\
\hline
\end{tabular}


Table 5. High-frequency keywords for marine social support policy samples of marine ecological civilization in Shandong province.

\begin{tabular}{|c|c|c|c|c|c|c|c|}
\hline Keywords & Frequency & Keywords & Frequency & Keywords & Frequency & Keywords & Frequency \\
\hline $\begin{array}{l}\text { Marine Technological } \\
\text { Innovation }\end{array}$ & 6 & Supervision and Inspection & 3 & $\begin{array}{l}\text { Major Scientific } \\
\text { Projects }\end{array}$ & 2 & Uninhabited Island & 2 \\
\hline Sea Use Management & 5 & $\begin{array}{l}\text { Industry-University-Research } \\
\text { Cooperation }\end{array}$ & 3 & Financial Support & 2 & $\begin{array}{c}\text { Integration of } \\
\text { Technology Industry }\end{array}$ & 2 \\
\hline $\begin{array}{c}\text { Application Materials } \\
\text { Procedure }\end{array}$ & 5 & $\begin{array}{l}\text { Innovative Development of } \\
\text { The Marine Economy }\end{array}$ & 3 & $\begin{array}{l}\text { Level-to-Level } \\
\text { Administration }\end{array}$ & 2 & Marine Equipment & 2 \\
\hline $\begin{array}{l}\text { Marine Environment } \\
\text { Protection }\end{array}$ & 4 & Marine Biomedicine & 3 & $\begin{array}{c}\text { Technology } \\
\text { Collaborative } \\
\text { Innovation Center }\end{array}$ & 2 & $\begin{array}{l}\text { Joint Working } \\
\text { Meeting }\end{array}$ & 2 \\
\hline $\begin{array}{l}\text { Marine Function } \\
\text { Zoning }\end{array}$ & 4 & $\begin{array}{l}\text { Transformation of Marine } \\
\text { Scientific And Technological } \\
\text { Achievements }\end{array}$ & 3 & $\begin{array}{l}\text { Management of Fishing } \\
\text { Boats and Fishermen }\end{array}$ & 2 & $\begin{array}{l}\text { Fishery Law } \\
\text { Enforcement }\end{array}$ & 2 \\
\hline Project Management & 4 & Marine Law Enforcement & 3 & Sea Island Protection & 2 & Ways of Auction & 2 \\
\hline $\begin{array}{c}\text { Final Acceptance } \\
\text { Management }\end{array}$ & 3 & $\begin{array}{l}\text { Marine Ecological Protection } \\
\text { and Restoration }\end{array}$ & 3 & Marine Ranching & 2 & Funds Management & 2 \\
\hline Marine Economy & 3 & Sea Area Utilization & 3 & $\begin{array}{c}\text { Marine Environmental } \\
\text { Monitoring }\end{array}$ & 2 & $\begin{array}{l}\text { Talent Introduction } \\
\text { and Training }\end{array}$ & 2 \\
\hline Use Right Auction & 3 & Uninhabited Island Use Right & 2 & Territory Management & 2 & Marine New Material & 2 \\
\hline Seafood Quality Safety & 3 & Marine Disaster Prevention & 2 & $\begin{array}{c}\text { Examination and } \\
\text { Evaluation }\end{array}$ & 2 & $\begin{array}{l}\text { Capability of } \\
\text { Independent } \\
\text { Innovation }\end{array}$ & 2 \\
\hline
\end{tabular}

Province can be obtained. Each node indicates a policy point, and the name of the policy point is marked; the line between the nodes indicates that the two keywords have the relationship of co-occurrence, and the thickness of the line indicates the frequency of co-occurrence between each two keywords, that is, the strength of the relationship between the two keywords. The analysis results are shown in Figure 4.

From the statistical results in Table 6, it can be known that the keywords with the highest degree of centrality in the comprehensive policies of marine ecological civilization in Shandong Province are marine technological innovation and marine ecological protection and restoration, which reached 72.093 , indicating that these two policy points occupy the most important position in the comprehensive policy system of marine ecological civilization construction in Shandong province from 2001 to 2019. Behind these two are keywords such as marine environmental monitoring, land-sea coordination, integrated marine management, marine environmental protection, etc., indicating that these policy points also occupy an important position in the policy social network, and together with marine technological innovation and marine ecological protection and restoration, these keywords constitute the core layer of the comprehensive policy system of marine ecological civilization construction in Shandong province.

According to the calculation results in Table 6, it can be seen that the comprehensive policy system of marine ecological civilization construction in Shandong Province is mainly focused on marine technological innovation, marine 


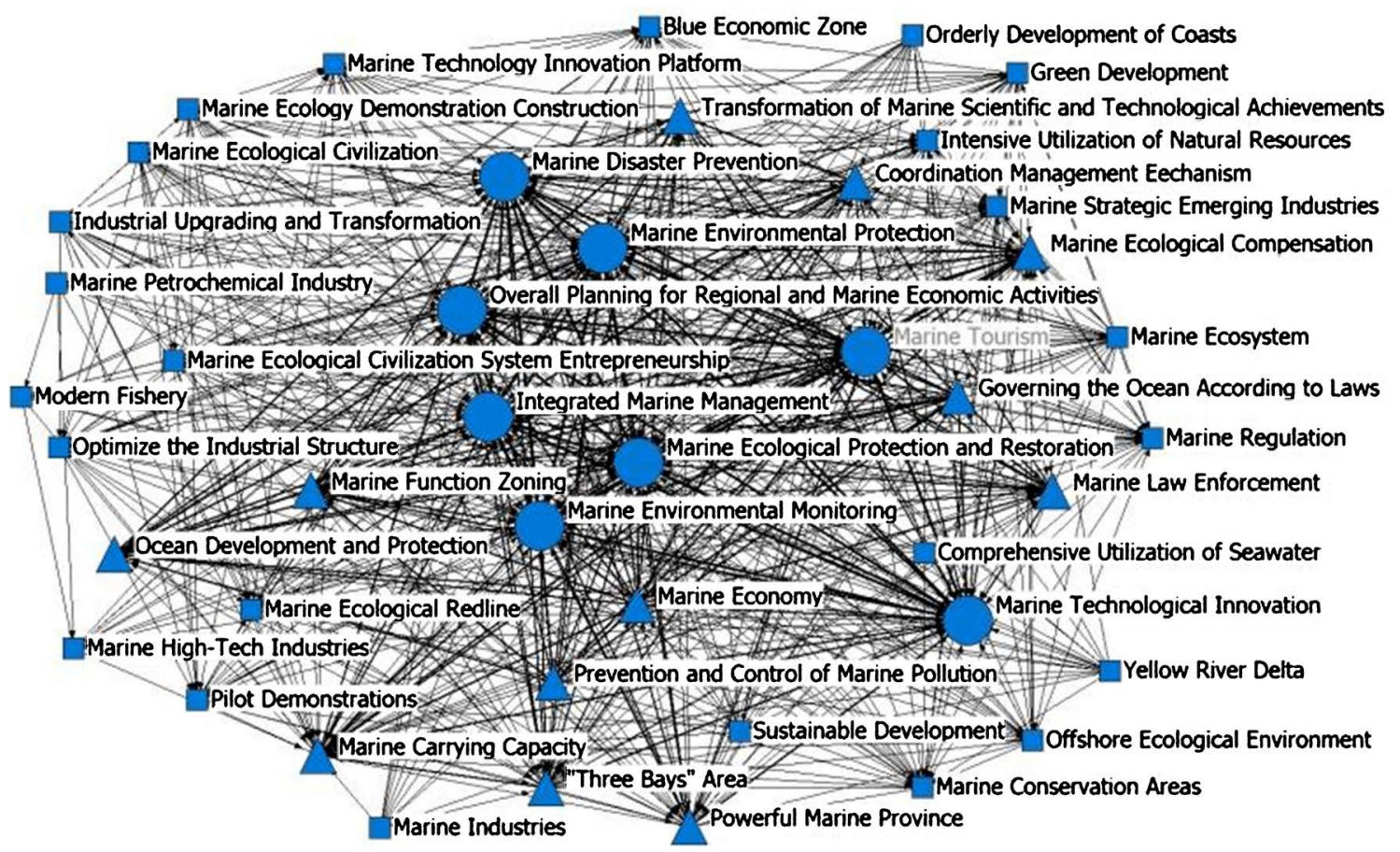

Figure 4. Social network diagram for high-frequency words in comprehensive policies of marine ecological civilization construction in Shandong province.

Table 6. Centrality ranking of high-frequency keywords for comprehensive policies of marine ecological civilization in Shandong province.

\begin{tabular}{|c|c|c|c|c|c|}
\hline Ranking & Keywords & Degree & Ranking & Keywords & Degree \\
\hline 1 & Marine Technological Innovation & 72.093 & 2 & Marine Ecological Protection and Restoration & 72.093 \\
\hline 3 & Marine Environmental Monitoring & 71.764 & 4 & Land-Sea Coordination & 71.256 \\
\hline 5 & Integrated Marine Management & 70.883 & 6 & Marine Environmental Protection & 70.012 \\
\hline 7 & Marine Disaster Prevention & 68.372 & 8 & Marine Tourism & 66.534 \\
\hline 9 & Marine Carrying Capacity & 65.116 & 10 & Marine Ecological Compensation & 61.863 \\
\hline 11 & “Three Bays” Area & 61.395 & 12 & Powerful Marine Province & 60.000 \\
\hline 13 & Marine Economy & 57.674 & 14 & Ocean Development and Protection & 56.744 \\
\hline 15 & Coordination Management Mechanism & 56.744 & 16 & $\begin{array}{c}\text { Transformation of Marine Scientific and } \\
\text { Technological Achievements }\end{array}$ & 56.279 \\
\hline 17 & Marine Law Enforcement & 56.279 & 18 & Marine Function Zoning & 55.814 \\
\hline 19 & Governing the Ocean According to Laws & 55.814 & 20 & Prevention and Control of Marine Pollution & 53.023 \\
\hline$\cdots$ & $\cdots$ & $\cdots$ & & $\ldots$ & .. \\
\hline 43 & Modern Fishery & 38.14 & 44 & Marine Petrochemical Industry & 37.209 \\
\hline
\end{tabular}

environmental protection, marine ecological protection and restoration, land-sea coordination, integrated marine management and so on. Among them, marine functional zoning, marine environmental protection, marine ecological protection and restoration, marine disaster prevention, and marine environmental monitoring are keywords with high frequency of occurrence and high 
betweenness centrality, and they are closely related as a whole, indicating that Shandong province is building a marine ecological protection system that engages in pre-monitoring and prevention, in-process protection and post-repair, supplemented by land-sea coordination, which can strengthen the marine ecological civilization construction from some sources. In addition, keywords such as marine technological innovation, transformation of marine scientific and technological achievements, marine high-tech industries, marine technological innovation platforms, and marine strategic emerging industries are also connected to a certain extent and have formed a policy focus cluster.

This indicates that in the future development of the marine economy, Shandong province will increase the support of marine society, especially the support of marine science and technology; on the basis of focusing on the maintenance of the original marine ecosystem, Shandong province will continue to optimize the structure of the marine industry and promote industrial upgrading and transformation, take the pilot demonstration of marine ecology as the benchmark, achieve the coordination of marine development and protection within the carrying capacity, build the legal marine governance system and comprehensive management mechanism including strict marine law enforcement and marine supervision, and strive to promote the province's marine economy to the direction of resource-intensive, environmentally friendly development.

2) Node Centrality Analysis

According to the high-frequency words of the ecological civilization policies of Shandong Province, $44{ }^{\star} 44,42 \star 42,41{ }^{\star} 41$, and $40 \star 40$ co-word matrixes of policy keywords for marine ecological civilization construction policies were constructed. In the matrixes, the number of diagonal lines is the total number of times a keyword appears, and the data in row A and column B is the number of times that keyword A and keyword B appear simultaneously in the innovation policy set. After loading the generated matrixes into the Netdraw visualization software, the social network diagrams of keywords for marine ecological civilization policies in Shandong Province can be obtained. Each node indicates a policy point, and the name of the policy point is marked; the line between the nodes indicates that the two keywords have the relationship of co-occurrence, and the thickness of the line indicates the frequency of co-occurrence between each two keywords, that is, the strength of the relationship between the two keywords. The analysis results are shown in Figure 5.

Node centrality is an indicator that measures the status and importance of each policy keyword in the co-word social network. It reflects the rights or status of network actors in social networks, and can be categorized into degree centrality, closeness centrality and betweenness centrality. Degree centrality indicates the number of other nodes directly connected to a certain node. The higher the value of degree centrality of a keyword, the stronger its centrality. In combination with the context of this paper, this keyword may be a hotspot issue of innovation policies. Betweenness centrality characterizes the degree to which a node 


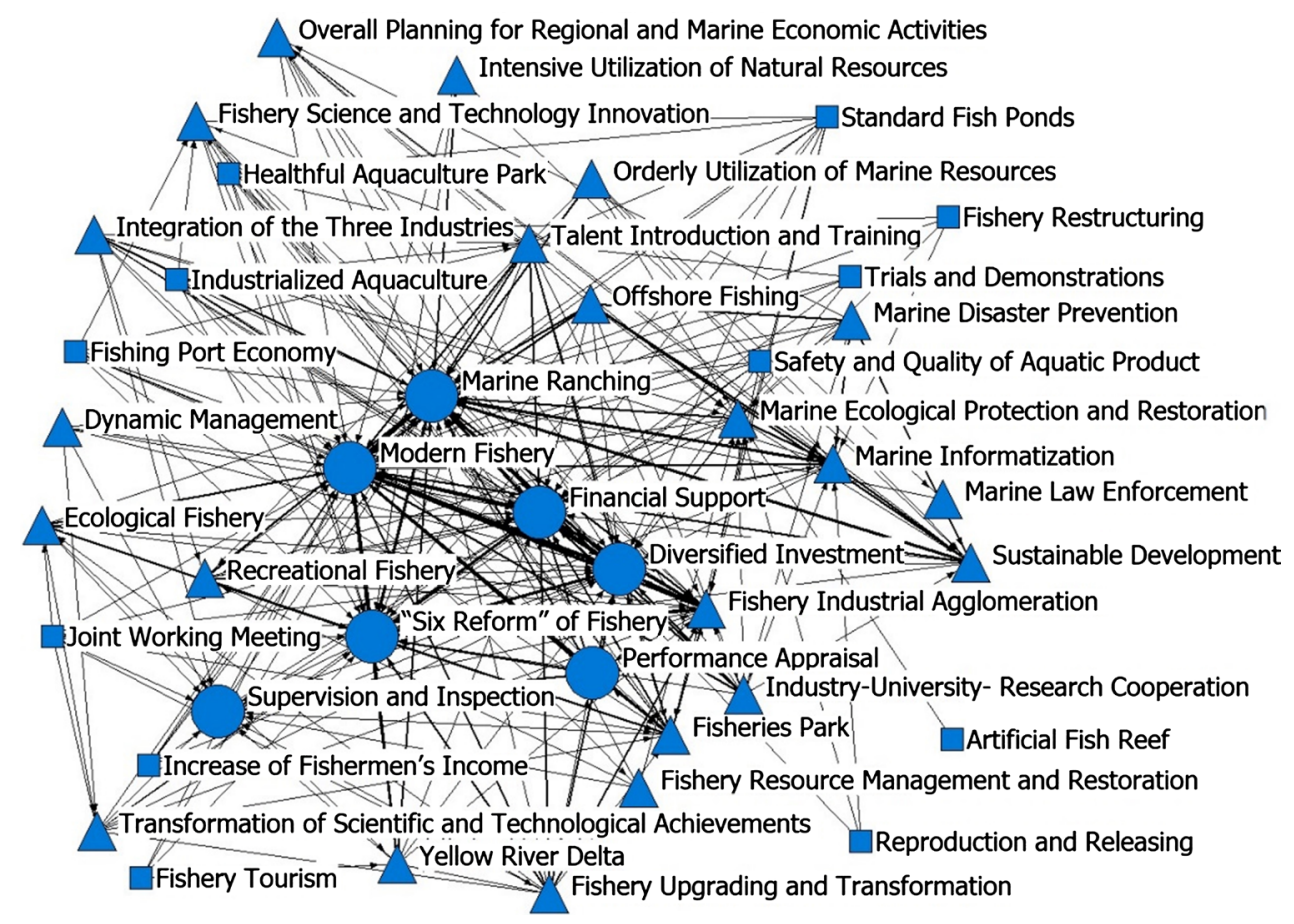

Figure 5. Social network diagram for high-frequency words in marine economic policies of marine ecological civilization construction in Shandong province.

is located "in the middle" of other nodes. The higher the value of betweenness centrality of a keyword, the stronger its control over resources. Closeness to centrality represents the sum of the shortest path distances between a node and other nodes. The smaller the sum of the distances, the higher the closeness centrality. This paper mainly uses the value of point centrality to define the node centrality of policy keywords, and to analyze their position in the policy social network. The calculation formula of point centrality is shown as follows.

Point Centrality: $C_{p}(i)=d_{i} /(n-1)$

The node centrality of policies of marine ecological civilization construction in Shandong province is shown in Table 3.

As can be seen from Table 7, the keywords with the highest degree of centrality in marine economic policies for marine ecological civilization construction in Shandong Province are marine ranching and modern fishery, which have reached 58.130 and 57.317 respectively. This shows that these two policy points occupy the most important position in the economic policy system of marine ecological civilization construction in Shandong province from 2001 to 2019. Behind these two are keywords such as financial support, diversified investment, "six reform" of fishery, fishery industrial agglomeration, etc.; these keywords are also the focal points in the social network, and together with marine ranching and modern fishery, these keywords constitute the core layer of the economic policy system of marine ecological civilization construction in Shandong province.

The economic policy system for marine ecological civilization construction in Shandong Province mainly focuses on marine ranching, modern fishery, "six 
Table 7. Centrality ranking of high-frequency keywords for marine economic policies of marine ecological civilization in Shandong province.

\begin{tabular}{|c|c|c|c|c|c|}
\hline Ranking & Keywords & Degree & Ranking & Keywords & Degree \\
\hline 1 & Marine Ranching & 58.130 & 2 & Modern Fishery & 57.317 \\
\hline 3 & Financial Support & 52.439 & 4 & Diversified Investment & 52.439 \\
\hline 5 & "Six Reform" of Fishery & 49.187 & 6 & Fishery Industrial Agglomeration & 44.715 \\
\hline 7 & Talent Introduction and Training & 38.211 & 8 & Fisheries Park & 36.992 \\
\hline 9 & Marine Informatization & 36.179 & 10 & Recreational Fishery & 34.959 \\
\hline 11 & Integration of the Three Industries & 34.146 & 12 & $\begin{array}{c}\text { Marine Ecological Protection and } \\
\text { Restoration }\end{array}$ & 33.333 \\
\hline 13 & Fishery Upgrading and Transformation & 33.333 & 14 & Sustainable Development & 32.927 \\
\hline 15 & $\begin{array}{l}\text { Industry-University-Research } \\
\text { Cooperation }\end{array}$ & 32.927 & 16 & Yellow River Delta & 32.927 \\
\hline 17 & Supervision and Inspection & 32.520 & 18 & Offshore Fishing & 31.301 \\
\hline 19 & Performance Appraisal & 31.301 & 20 & Fishery Science and Technology Innovation & 31.301 \\
\hline$\cdots$ & $\cdots$ & $\ldots$ & & $\cdots$ & .. \\
\hline 41 & Selective Breeding & 17.886 & 42 & Artificial Fish Reef & 17.073 \\
\hline
\end{tabular}

reform" of fishery, financial support and diversified investment. Through financial investment, and guiding diversified investment into the construction of marine ranching, Shandong province quickens the transition of traditional fishery to modern fishery by achieving technicalization, parklization, brandization, organization, scalization, and industrialization, and has the projects that the finance funds invests carry on supervision and inspection and performance appraisal, thus guarantees the economic benefit. Here, the modern fishery includes recreational fishery, offshore fishery, ecological fishery, etc., which are carried out through industrial agglomeration methods such as industrialized aquaculture, healthful aquaculture, and developing fishing port economy. Based on the intensive use of resources, artificial fish ponds and reproduction and releasing are constructed, the marine ecological protection and the management and restoration of fishery resources are paid attention to, so as to achieve the sustainable development of marine economy.

In terms of fishery transformation and upgrading, through the industry-university-research cooperation in the marine industry, Shandong province promotes fishery science and technology innovation and the transformation of marine scientific and technological achievements in the fishery park, including selection and breeding of fine species, and ensures the prevention of marine disasters and improves the safety and quality of aquatic products through the construction of marine informatization systems. However, from the perspective of the overall social network, the marine economic policies for marine ecological civilization construction in Shandong Province are mainly focused on traditional formats such as fisheries and aquaculture. For high-tech, high value-added in- 
dustries that involve the marine economy such as ship equipment manufacturing, marine biomedicine, marine tidal energy utilization, etc. the marine economic policies do not focus much, which may be because of the limitation of the scope of powers and responsibilities of the Department of Marine Affairs and Fishery (now the Oceanic Administration), the main management department. The analysis results are shown in Figure 6.

According to the calculation of the betweenness centrality of the marine environmental policies social network in Table 8, it can be known that the keyword with the highest centrality in the marine environmental policies of marine ecological civilization construction in Shandong Province is marine environmental protection, with a betweenness centrality of 44.500 , occupying a core position in the marine environmental protection policy system in Shandong province. Behind it are keywords such as prevention and control of marine pollution, marine ecological protection and restoration, overall planning for regional and marine economic activities, marine disaster prevention, marine ecological redline, etc. These are also the main policy points in social networks. Together with marine environmental protection, these keywords constitute the inner circle of the marine environmental policy system of marine ecological civilization construction in Shandong Province. It is worth noting that the betweenness centrality of the keyword marine ecological civilization construction is only 19.000, which is consistent with its relatively low frequency of occurrence. This may be due to the short development process of ecological civilization construction, which leads to its relatively minor position in the policy texts and social network. The statistical results are shown in Table 8.

The marine environmental policies of marine ecological civilization construction

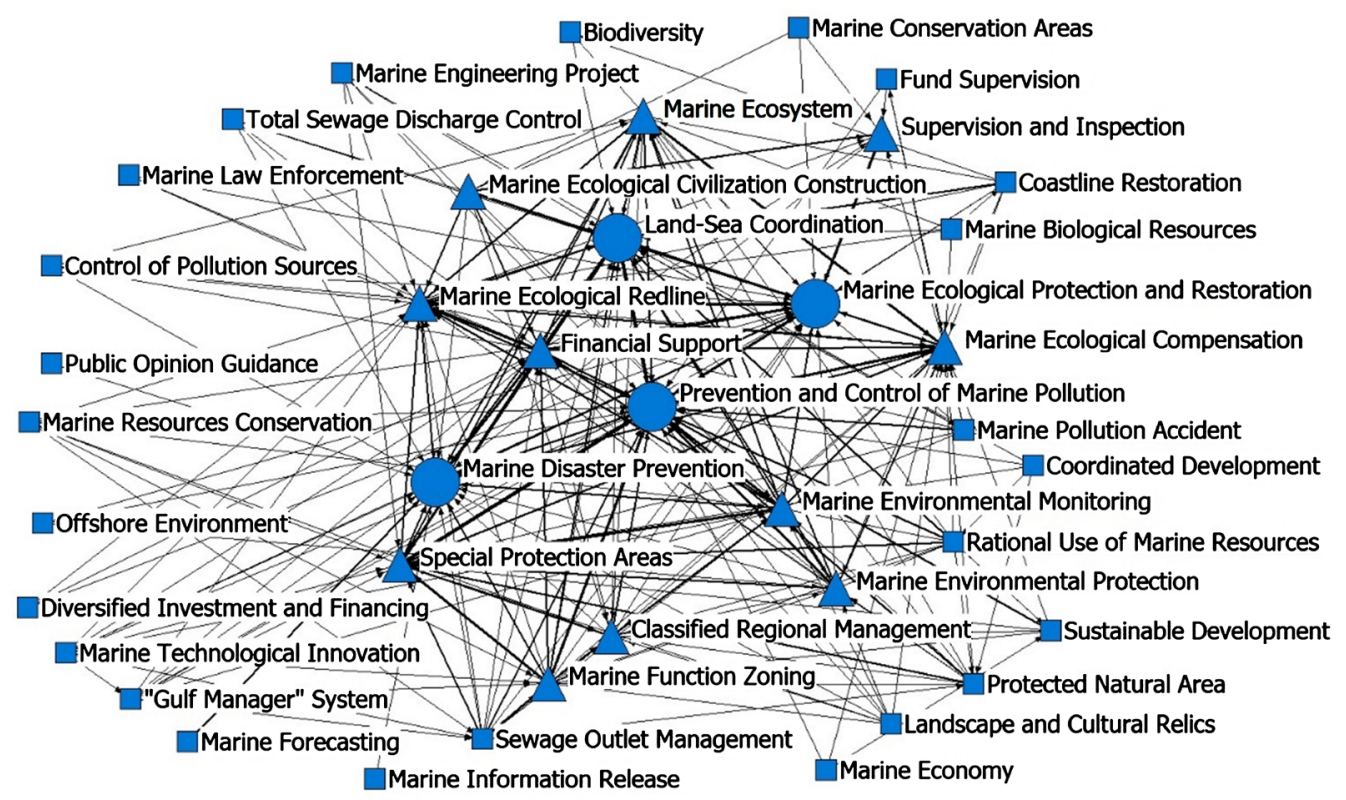

Figure 6. Social network diagram for high-frequency words in marine environmental policies of marine ecological civilization construction in Shandong province. 
Table 8. Centrality ranking of high-frequency keywords for marine environmental policies of marine ecological civilization in Shandong province.

\begin{tabular}{|c|c|c|c|c|c|}
\hline Ranking & Keywords & Degree & Ranking & Keywords & Degree \\
\hline 1 & Marine Environmental Protection & 44.500 & 2 & Prevention and Control of Marine Pollution & 38.000 \\
\hline 5 & Marine Disaster Prevention & 36.500 & 6 & Marine Ecological Redline & 36.000 \\
\hline 7 & Special Protection Areas & 36.000 & 8 & Marine Ecological Compensation & 35.500 \\
\hline 9 & Financial Support & 35.500 & 10 & Marine Ecosystem & 32.000 \\
\hline 11 & Marine Function Zoning & 30.500 & 12 & Marine Environmental Monitoring & 28.000 \\
\hline 13 & Classified Regional Management & 25.500 & 14 & Sewage Outlet Management & 23.000 \\
\hline 15 & Protected Natural Area & 22.500 & 16 & Rational Use of Marine Resources & 19.500 \\
\hline 19 & “Gulf Manager” System & 18.000 & 20 & Supervision and Inspection & 18.000 \\
\hline$\cdots$ & $\cdots$ & $\cdots$ & & $\cdots$ & $\cdots$ \\
\hline 41 & Public Opinion Guidance & 1.500 & & & \\
\hline
\end{tabular}

in Shandong Province mainly focus on marine ecological protection and restoration, marine environmental protection, marine disaster prevention, prevention and control of marine pollution, overall planning for regional and marine economic activities, supervision and inspection, marine ecological compensation, classified regional management, marine ecological redline, etc. In terms of coverage, they are relatively comprehensive, and are also in line with the focus of marine ecological civilization construction at this stage. In the aspect of protection operations, Shandong province mainly zones different marine function areas, so as to determine the marine key protection areas and special protection areas by the way of classified regional management. The analysis results are shown in Figure 7.

In addition, in terms of marine protection, Shandong province also controls the total amount of pollutants discharged from land pollution sources and sewage outlets by means of land-sea coordination, conducts real-time marine environmental monitoring, innovates the "gulf manager" system to arrange managers to take charge of certain areas, strengthens the administrative law enforcement in marine environmental protection, and strengthens the restoration of coastline and offshore waters. In terms of marine disaster prevention and control, Shandong Province has also established a corresponding marine disaster prevention and control information system, which uniformly predicts and releases news, and has established a graded alert mechanism. However, on the other hand, Shandong Province's marine environmental policies have insufficient guidance for the construction of marine ecological civilization, especially for the protection and restoration of marine ecological environment. The support for marine environmental protection technology industry also needs to be 
strengthened.

From the calculation of the centrality of marine social support policies social network in Table 9, it can be known that keyword with the highest betweenness centrality in the marine social support policies of marine ecological civilization construction in Shandong Province is marine technological innovation, with a betweenness centrality of 41.667 , which is far higher than other policy points and becomes the core policy point of the whole social network. Behind it are

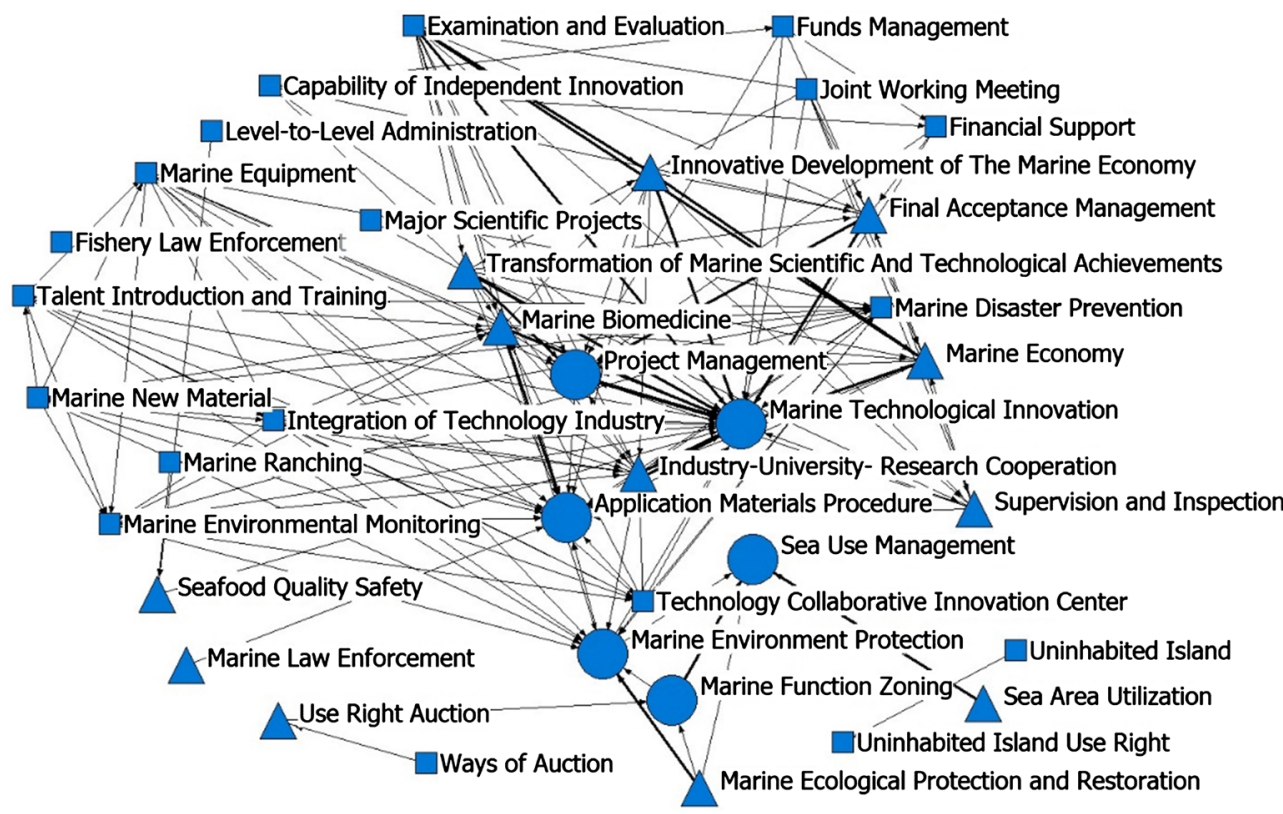

Figure 7. Social network diagram for high-frequency words in marine social support policies of marine ecological civilization construction in Shandong province.

Table 9. Centrality ranking of high-frequency keywords for marine social support policies of marine ecological civilization in Shandong province.

\begin{tabular}{|c|c|c|c|c|c|}
\hline Ranking & Keywords & Degree & Ranking & Keywords & Degree \\
\hline 1 & Marine Technological Innovation & 41.667 & 2 & Application Materials Procedure & 33.333 \\
\hline 3 & Marine Biomedicine & 29.487 & 4 & Project Management & 29.487 \\
\hline 5 & Industry-University-Research Cooperation & 26.923 & 6 & Marine Environmental Protection & 26.282 \\
\hline 7 & $\begin{array}{c}\text { Transformation of Marine Scientific And } \\
\text { Technological Achievements }\end{array}$ & 25.641 & 8 & Marine Economy & 24.359 \\
\hline 9 & Innovative Development of the Marine Economy & 23.718 & 10 & Examination and Evaluation & 23.718 \\
\hline 11 & Marine Equipment & 21.795 & 12 & Integration of Technology Industry & 21.154 \\
\hline 13 & Marine New Material & 21.154 & 14 & Technology Collaborative Innovation Center & 21.120 \\
\hline 15 & Marine Disaster Prevention & 20.558 & 16 & Marine Environmental Monitoring & 20.376 \\
\hline 17 & Talent Introduction and Training & 19.763 & 18 & Final Acceptance Management & 17.949 \\
\hline 19 & Supervision and Inspection & 16.667 & 20 & Seafood Quality Safety & 16.667 \\
\hline \multicolumn{6}{|l|}{$\cdots$} \\
\hline 39 & Territory Management & 1.923 & 40 & Management of Fishing Boats and Fishermen & 0.641 \\
\hline
\end{tabular}


keywords such as application materials procedure, program management, marine biomedicine, industry-university-research cooperation, transformation of marine scientific and technological achievements, etc. Together with marine technological innovation, these keywords constitute the social support policy network for marine ecological civilization construction in Shandong province. The statistical results are shown in Table 9.

Based on the calculation results, in general, marine social support policies in Shandong Province mainly include two aspects of marine technological innovation and marine area management, with marine technological innovation, marine environmental protection, marine functional zoning, and sea use management as the core points. In terms of marine technological innovation, Shandong Province will mainly establish technology collaborative innovation centers, take major scientific research projects as the starting point, increase the intensity of talent introduction and industry-university-research cooperation, and promote the transformation of marine high-tech achievements represented by marine biomedicine and marine equipment manufacturing, and promote the transformation, upgrading and innovative development of the marine economy by combining marine science and technology with marine industry [8]. In terms of marine ecological management, Shandong province will mainly manage marine areas and their uses through marine functional zoning, and pay attention to the protection of the marine environment and marine ranching in relevant marine areas [9].

\subsection{Analysis of Overall Results of Policy Social Networks}

Through the drawing of the social network diagram of marine ecological civilization construction in Shandong Province and the analysis of node centrality, this paper finds that the coverage of the policy social network is relatively comprehensive, and the social network of policy keywords is also relatively systematic. In general, there are the following characteristics:

1) The comprehensive policy system for the marine ecological civilization construction in Shandong Province is mainly built around two aspects, respectively marine ecology and marine environment, and marine technological innovation. The proportion of marine economy is not high, which is also consistent with the national direction of ecological civilization construction. But to a certain extent, this may also affect the coupling between marine ecological economy, marine ecological environment and marine ecological social support.

2) In terms of the marine economic policy system, it is mainly limited to the construction of marine ranches and the upgrading and transformation of traditional fishery to modern fishery. More attention is paid to the aspects such as the deep processing of aquatic products, reproduction and releasing, while not much attention is paid to the high-tech and high-value-added emerging industries in the marine economy. Looking back on the emergence of marine technological innovation in the policy texts, it can be found that marine technological innova- 
tion is also closely related to the modern fishery building, the research and development of improved aquatic species, marine informatization and marine equipment, and is limited to the application in traditional industries. This may also lead to a policy disconnection when marine technological innovation is clearly the core of marine social support policies.

\section{Summary and Outlook}

In the domestic context, the process of marine ecological civilization construction is deeply affected by related policies. Therefore, it is of great significance to analyze the policy system of marine ecological civilization construction in Shandong Province. This paper divides China's marine ecological civilization related policies into three stages, and selects the third stage, the stage from 2001 to the present, and sorts out the marine ecological civilization policies in Shandong province during this period. A total of 54 related marine ecological civilization policies in Shandong Province are retrieved; combined with the evaluation index system in chapter four, they are divided into 5 comprehensive planning policies, 15 marine economic policies, 17 marine environmental policies and 17 marine social support policies. Except for fewer comprehensive planning policies, the number of marine economic policies, marine environmental policies, and marine social support policies is relatively balanced.

After a study on the main body of policy formulation of marine ecological civilization construction in Shandong province, this paper finds that there are multiple participants. In addition to the Department of Marine Affairs and Fisheries (now the Oceanic Administration), which is the competent department, the Provincial Party Committee, the Provincial Government, the Development and Reform Commission, the Department of Ecology and Environment and the Department of Finance have also participated, showing the characteristics of diversity. However, the consultation and decision-making cooperation among policy makers is insufficient on the whole, and the coordination of policy release is not high. The number of joint decisions and releases only accounts for about a quarter of the total number of policies, which indicates that the policy making is dominated by the single decision-making mode, and the joint decision-making is very rare.

In terms of content research on the policies of marine ecological civilization construction in Shandong Province, this paper uses the social network method to quantify the content of the policy system, constructs $44 * 44,42 \star 42,41 * 41$, and $40 * 40$ co-word matrixes respectively, and uses the social network analysis tool Ucinet to generate a visualized social network diagram of policy core contents, so as to present the status quo and focus of the policy system of marine ecological civilization construction in Shandong province in a visualized way. In addition, this paper also calculates and analyzes the central point of the policy social network of marine ecological civilization construction in Shandong province. It is found that among the comprehensive policies of marine ecological ci- 
vilization construction in Shandong Province, the marine ecological environment protection policies have more focuses and have formed a relatively complete system. However, the degree of relevance of marine technological innovation policy points related to marine social support policies is not high, and the support for marine environmental protection technology innovation is not strong. These discoveries are also reflected in the subsequent content analysis of marine social support policies, and they also affect the coupling degree of marine ecological environment and society in Shandong province to a certain extent. In addition, the marine economic policies of marine ecological civilization construction in Shandong province are still mainly focused on traditional business forms such as fishery and aquaculture, and high-tech, high-value-added industries involved in the marine economy are not concerned much; however, industry-university-research cooperation on marine science and technology is mentioned in the marine social support policies. This also indicates that there exists the phenomenon of policy disconnection to a certain extent.

\section{Conflicts of Interest}

The author declares no conflicts of interest regarding the publication of this paper.

\section{References}

[1] Xu, L.N., Bi, Y.L. and Chen, C.Z. (2014) Analysis on the Types of Current Marine Policies in China. Ocean Development and Management, 31, 9-13.

[2] Wang, G. and Liu, Y. (2012) Discussion on the Basic Issues of Marine Policy. Journal of Ocean University of China: Social Science Edition, No. 1, 16-20.

[3] Zhang, G.Q. (1997) Introduction to Modern Public Policy. Peking University Press, Beijing.

[4] Wang, G. and Mao, Y. (2019) Attention Changes in Marine Environmental Governance: Analysis Based on Policy Content and Social Networks. Journal of Ocean University of China, No. 1, 29-37.

[5] Zhang, H.Z. (2016) The Evolution of Marine Policies in the Government Work Report-Analysis of the Content of the Government Work Report of the State Council from 1954 to 2015. Journal of Shanghai Administration Institute, No. 3, 205-111.

[6] Zhang, Y. (2017) Construction of Marine Ecological Civilization Demonstration Area: Connotation, Problems and Optimization Paths. China Marine Sociology Research, 50-62.

[7] Zhao, X., Zhu, L.L. and Ding, L.L. (2017) The Realization Path of Marine Ecological Civilization Construction Under the Strategy of Innovation-Driven Development.

[8] Miles, E.L. (1999) The Concept of Ocean Governance: Evolution Toward the 21st Century and the Principle of Sustainable Ocean Use. Coastal Management, 27, 1-30. https://doi.org/10.1080/089207599263875

[9] Gare, A. (2010) Toward an Ecological Civilization. Process Studies, 39, 5-38. https://doi.org/10.5840/process20103912 